Article

\title{
Techno-Economic Comparative Analysis of Renewable Energy Systems: Case Study in Zimbabwe
}

\author{
Loiy Al-Ghussain $1, *\left(\mathbb{D}\right.$, Remember Samu ${ }^{2}\left(\mathbb{D}\right.$, Onur Taylan ${ }^{3,4}$ and Murat Fahrioglu $^{4,5}(\mathbb{D}$ \\ 1 Mechanical Engineering Department, University of Kentucky, Lexington, KY 40506, USA \\ 2 Discipline of Engineering and Energy, College of Science, Health, Engineering and Education, \\ Murdoch University, South Street, Murdoch, WA 6150, Australia; 33635333@student.murdoch.edu.au \\ 3 Mechanical Engineering Program, Middle East Technical University Northern Cyprus Campus, \\ Guzelyurt via Mersin 10, 99738 Kalkanli, Turkey; ontaylan@metu.edu.tr \\ 4 Center for Solar Energy Research and Applications (GÜNAM), Middle East Technical University, \\ 06800 Ankara, Turkey; fmurat@metu.edu.tr \\ 5 Electrical and Electronics Engineering Program, Middle East Technical University Northern Cyprus Campus, \\ Guzelyurt via Mersin 10, 99738 Kalkanli, Turkey \\ * Correspondence: loiy.al-ghussain@uky.edu
}

Received: 12 June 2020; Accepted: 3 July 2020; Published: 6 July 2020

\begin{abstract}
Fluctuations in fossil fuel prices significantly affect the economies of countries, especially oil-importing countries, hence these countries are thoroughly investigating the increase in the utilization of renewable energy resources as it is abundant and locally available in all the countries despite challenges. Renewable energy systems (RES) such as solar and wind systems offer suitable alternatives for fossil fuels and could ensure the energy security of countries in a feasible way. Zimbabwe is one of the African countries that import a significant portion of its energy needs which endanger the energy security of the country. Several studies in the literature discussed the feasibility of different standalone and hybrid RES either with or without energy storage systems to either maximize the technical feasibility or the economic feasibility; however, none of the studies considered maximizing both feasibilities at the same time. Therefore, we present a techno-economic comparison of standalone wind and solar photovoltaic (PV) in addition to hybrid PV/wind systems based on maximizing the RES fraction with levelized cost of electricity (LCOE) being less than or equal to the local grid tariff where Gwanda, Zimbabwe, is the case study. The methodology suggested in this study could increase the utilization of renewable energy resources feasibly and at the same time increase the energy security of the country by decreasing dependency on imported energy. The results indicate that the PV/wind hybrid system does not only have the best economic benefits represented by the net present value (NPV) and the payback period (PBP), but also the best technical performance; where the maximum feasible size of the hybrid system-2 MW wind and 1 MW PV-has RES fraction of $65.07 \%$, LCOE of $0.1 \mathrm{USD} / \mathrm{kWh}$, PBP of 3.94 years, internal rate of return of $14.04 \%$ and NPV of $3.06 \times 10^{6}$ USD. Having similar systems for different cities in Zimbabwe will decrease the energy bill significantly and contribute toward the energy security of the country.
\end{abstract}

Keywords: hybrid systems; photovoltaic; wind energy; energy economics; RES investments; Zimbabwe; Africa and energy security

\section{Introduction}

Environmental protection, energy resources conservation, and sustainable energy development are the core challenges that the world is facing nowadays [1] especially in hard times when crises have prevailed [2,3]. Moreover, given that the demand for electricity or rather energy is continuously 
increasing, being able to meet this demand in an environmentally friendly manner is of importance. Enterprises are constantly searching for upgrades in their procedures for better use [4-6]. Moreover, the issue is taken care of by utilizing clean power [7,8], usage of waste power [9] and implementing various arrangements $[10,11]$ where assets and condition are preserved. Henceforth, adjustments on power systems to expand force and productivity are required [12].

Zimbabwe faces a deficit in its energy production. Around 35\% of the energy used in Zimbabwe is imported from the Democratic Republic of Congo (DRC), South Africa and Mozambique [13]. Renewable energy can be an environmentally friendly and sustainable solution to help curb this energy deficit in Zimbabwe. Basic knowledge of the geographical location, economic situation, as well as energy demand, is required to design and develop suitable systems. Zimbabwe lies in a sunny belt, with approximately $4000 \mathrm{~h}$ of solar radiation per year and $5.5 \mathrm{kWh} / \mathrm{m}^{2} /$ day of solar radiation on average [14,15]. Renewable energy has not been harnessed on a large scale in Zimbabwe. Small-scale solar photovoltaic (PV) panels for lighting and irrigation purposes are the only uses of solar energy in Zimbabwe [13]. Small windmills still exist on some farms, in which they were once used to pump water even though a study by the ZERO Regional Environment Organization concluded that there is a potential of generating power from wind resources in Zimbabwe at a hub height of $80 \mathrm{~m}$ [13].

Renewable energy systems comprising individual resources and/or more hybrid power systems have been a topic of recent research worldwide [12,16-23]. The early research papers on hybrid power systems were published in the mid-1980s [24]. With the advances in research, in the early 1990s wind resources could now be harnessed on a commercial scale. The problem of intermittency, grid stability and reliability led to more expansion of literature on renewables as well as hybrid systems [25].

In literature, noteworthy efforts on feasibility studies on solar PV, wind and hybrid PV-wind power systems have been made both grid-connected or stand-alone systems $[17,18,26-33]$. Research on hybrid systems has been undertaken but the goals of each research project differ. For two different locations in Jordan $[34,35]$ used MATLAB and HOMER software to model economically feasible hybrid solar PV-wind power systems. Their main goal was to determine the cost of energy (COE), the net present value (NPV) and the renewable energy source (RES) fraction.

Benlouba and Bourouis [36] studied the economic and technical feasibility of different off-grid PV-wind hybrid configurations with diesel generators for a village in Algeria. Moreover, Ashok [37] found the configuration of a PV-wind hybrid system that has the lowest cost of electricity for a village in India using a Quasi-Newtonian method. He found out that a PV/wind/diesel/micro hydro hybrid system would provide electricity for a whole day at a cost of $0.14 \mathrm{USD} / \mathrm{kWh}$. Furthermore, Samu et al. [38] concluded that the LCOE of their hybrid PV-wind power system was greater than the grid tariff solely because they used a wind turbine prototype with high cut-in speed and the competing generation sources, coal and hydro are cheaper as well.

The first research on the analysis of the solar potential of the whole of Zimbabwe was undertaken by [13]. They concluded that solar PV generation is both economically and environmentally feasible in the whole of Zimbabwe. Further studies of solar PV resources in some parts of Africa were undertaken by $[15,39-44]$. In summary, solar is economically feasible in various parts of Africa. Studies on possible solar home systems to alleviate the current power challenges in Zimbabwe have been performed by Chahuruva and Dei [45]. In this study, the authors performed an experiment at Ashikaga Institute in Japan to obtain results which they believed could be transferable to Zimbabwe. Results of this study could be questionable since the geographical and weather conditions in Japan are different from those in Zimbabwe. Additionally, this analysis was performed at irradiation of $8.25 \mathrm{kWh} / \mathrm{m}^{2} /$ day against Zimbabwe's average irradiation of $5.72 \mathrm{kWh} / \mathrm{m}^{2} /$ day. Additionally, a study on the potential of Concentrated Solar Power (CSP) in Zimbabwe was performed and it was concluded that 71.4 GW can be generated from CSP [46]. A wind map of Africa was developed by [47] and concluded that on average Africa has an onshore wind potential at a height of $80 \mathrm{~m}$ through Geographic Information System (GIS) analysis. Another wind resource mapping exercise was undertaken by [48] for Kenya and the southern part of Africa. Research on the techno-economic potential of wind energy has been 
carried out for a remote area of Sahel Zone in Cameroon by $[49,50]$ did an assessment for another location in Cameroon as well and determined that the total energy produced annually could reduce carbon dioxide emissions by 1200 tons per year. Their calculated results and those of the Wind Atlas Analysis and Application Program (WAsP) were in good correlation [50].

The goals and objectives of the Zimbabwe National Renewable Energy Policy (NREP) included the installation of $1100 \mathrm{MW}$ of renewables by 2025 and $2100 \mathrm{MW}$ of renewables by 2030. Renewables in this context referred to grid-connected solar PV, grid-connected wind, small hydro and bagasse. The policy reported the provision of tax and sale of power to third-party incentives by the government and also reduced license fees for renewable energy projects. However, the policy does not outline any possible feed-in tariffs for renewable energy resources which might still make investments unattractive. Additionally, the policy still does not mention any development of stand-alone microgrids to electrify remote areas in which the rural electrification rate is only 13\% [51]. The NREP also reports that the Zimbabwean government will introduce mechanisms for funding renewable energy systems as well as implementing a renewable energy technologies program that encourages Independent Power Producers (IPPs) to invest in renewable energy projects in Zimbabwe. Additionally, a fund is to be established by the Ministry of Energy to promote solar energy to address the electricity crisis.

All of the papers reviewed for this study did not compare the economic and technical feasibilities of wind, PV and PV-wind hybrid system at the same location in order to determine the most suitable system and the most profitable one. Moreover, none of the studies in the literature considered maximizing both the technical and economic feasibilities of different standalone and hybrid PV/wind systems in Zimbabwe at the same time. Therefore, this study aims to perform a techno-economic comparative study of an on-grid wind, PV and PV/wind hybrid system to determine the best RES configuration to be installed where Gwanda, Zimbabwe, is the case study knowing that this methodology can be used to determine the best configuration to install in any region in the world. The optimal RES configurations were found based on maximizing the RES fraction with levelized cost of electricity being less than or equal to the local grid tariff; such a constraint will ensure the maximum environmental benefits of the systems, increase the energy security of the country and at the same time ensures the economic feasibility of the alternative energy systems. Such methodology will increase the utilization of the local and abundant renewable energy resources in oil-importing countries such as Zimbabwe which would count toward significant cuts in the imported energy bill. Moreover, the proposed methodology is in accordance with the NREP goals and provides a pathway to achieve these goals in Zimbabwe.

\section{Theory and Methodology}

\subsection{Photovoltaic (PV) Energy Model}

Energy production from the PV plant is affected by the ambient conditions; where the effect of the ambient temperature on the module efficiency is the only ambient condition considered in this study. The efficiency of the PV module can be estimated using Equation (1) [52].

$$
\eta_{\mathrm{PV}}=\eta_{\mathrm{PV}, \mathrm{R}} \times\left[1-\beta_{\mathrm{R}} \times\left(\mathrm{T}_{\mathrm{a}}+\left(\mathrm{T}_{\mathrm{NOC}}-\mathrm{T}_{\mathrm{R}, \mathrm{NOC}}\right) \times \frac{I_{T}}{\mathrm{I}_{\mathrm{R}}}-\mathrm{T}_{\mathrm{R}, \mathrm{STC}}\right)\right]
$$

where $\eta_{P V}$ is the photovoltaic module efficiency, $\eta_{P V, R}$ is the module reference efficiency, $\beta_{R}$ is the temperature coefficient $\left(1 /{ }^{\circ} \mathrm{C}\right), \mathrm{T}_{\mathrm{a}}$ is the ambient temperature $\left({ }^{\circ} \mathrm{C}\right)$ which was obtained for Gwanda city using Meteonorm v7.1 software which generates a typical meteorological year (TMY) [52], $\mathrm{T}_{\mathrm{NOC}}$ is the nominal operating cell temperature $\left({ }^{\circ} \mathrm{C}\right), \mathrm{T}_{\mathrm{R}, \mathrm{NOC}}$ is the reference module temperature at nominal conditions $\left({ }^{\circ} \mathrm{C}\right), I_{T}$ the total irradiation on a tilted surface $\left(\mathrm{Wh} \mathrm{m}^{-2}\right), \mathrm{I}_{\mathrm{R}}$ is the reference irradiation at nominal conditions $\left(\mathrm{Wh} \mathrm{m}^{-2}\right)$ and $\mathrm{T}_{\mathrm{R}, \mathrm{STC}}$ is the reference module temperature at standard test conditions $\left({ }^{\circ} \mathrm{C}\right)$. In this study, PV modules from Canadian Solar company (Guelph, Ontario, Canada) type CS6K-285M were used [53]. 
After estimating the global insolation on the photovoltaic module and, with the estimation of the PV module efficiency, the hourly energy generation from the photovoltaic plant can be found. Using the methodology in Duffie and Beckman [54], the global insolation was estimated which was not repeated in this study for brevity. The hourly energy generated, $E_{P}$, can be estimated as,

$$
\mathrm{E}_{\mathrm{P}}=\eta_{\mathrm{PV}} \times \mathrm{I}_{\mathrm{T}} \times \mathrm{A}_{\mathrm{m}} \times \mathrm{N}_{\mathrm{m}}
$$

where $A_{m}$ is the single module area $\left[\mathrm{m}^{2}\right]$ and $N_{m}$ is the number of PV modules.

\subsection{Wind Energy Model}

The wind shear coefficient $(\alpha)$ can represent the factors that affect the wind speed at hub height like the speed at ground level, the hub height, the time (hour, day, season), the nature of the terrain and the ambient temperature. $\alpha$ can be taken as $\frac{1}{7}$ if the specific data of the site is not available [55]. At hub height, the wind speed $\left(u_{\mathrm{Z}}\right)$ can be extrapolated as,

$$
u_{\mathrm{Z}}=\mathrm{u}_{\mathrm{g}} \times\left(\frac{\mathrm{Z}}{\mathrm{Z}_{\mathrm{g}}}\right)^{\alpha}
$$

where $u_{g}$ is the wind speed at ground level $(\mathrm{m} / \mathrm{s}), Z$ is the height of the hub $(\mathrm{m})$ and $Z_{\mathrm{g}}$ is the ground level height $(\mathrm{m})$ at which speed is measured and it is equal $10 \mathrm{~m}$. The hourly wind speeds at ground level for Gwanda city were generated using Meteonorm v7.1 software. Figure 1 shows the average hourly wind speeds at $10 \mathrm{~m}$ in addition to the average daily global insolation on a horizontal surface in Gwanda.

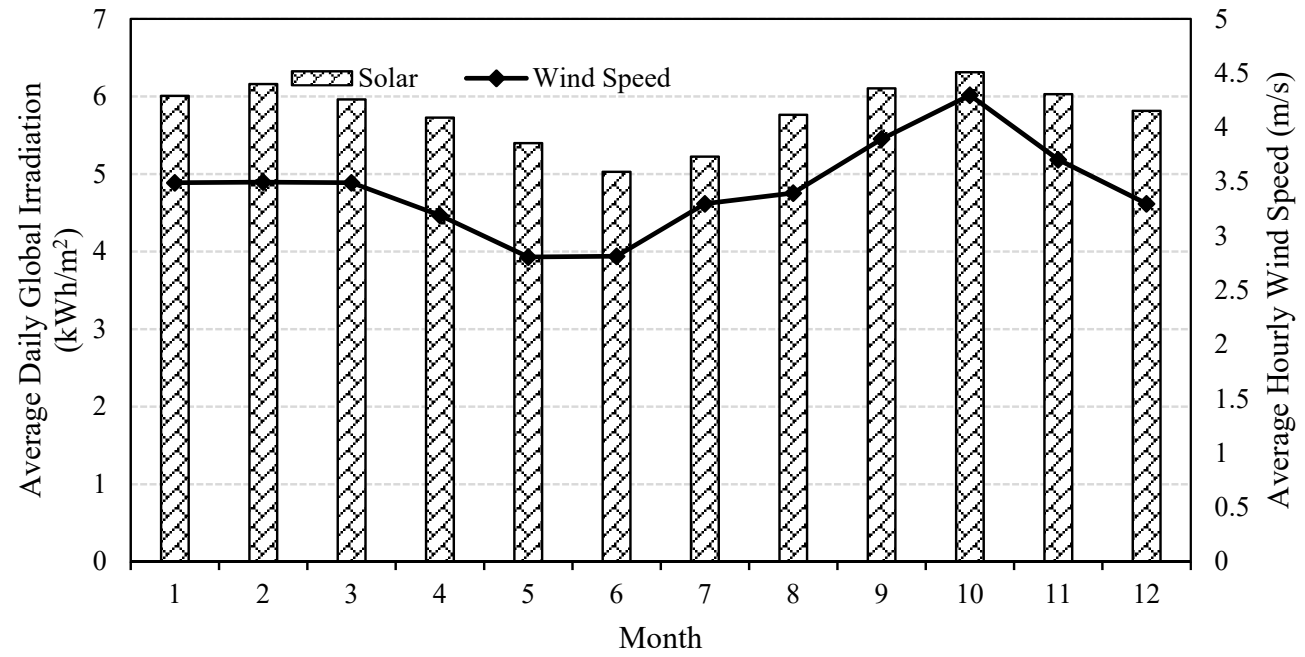

Figure 1. The average hourly wind speeds at ground level in addition to the average daily solar radiation on a horizontal surface throughout the year in Gwanda.

It is assumed that the energy generated from each wind turbine-in the case of multiple wind turbines-is the same; moreover, it is assumed that the energy production does not change during the hour. $\mathrm{E}_{\mathrm{w}}$ which is the hourly energy production can be estimated using Equation (4).

$$
\mathrm{E}_{\mathrm{w}}=\left\{\begin{array}{c}
0, u_{Z}\left\langle u_{C} \text { or } u_{Z}\right\rangle u_{F} \\
N \times P_{R} \times \frac{\left(u_{C}\right)^{K}-\left(u_{Z}\right)^{K}}{\left(u_{C}\right)^{K}-\left(u_{R}\right)^{K}}, u_{c} \leq u_{Z} \leq u_{R} \\
N \times P_{R}, u_{R}<u_{Z} \leq u_{F}
\end{array}\right.
$$

where $P_{R}$ is the wind turbine rated power $(\mathrm{kW}), N$ is the number of turbines, $\mathrm{u}_{C}$ is the wind turbine cut-in speed $(\mathrm{m} / \mathrm{s}), \mathrm{u}_{\mathrm{F}}$ is the furling speed $(\mathrm{m} / \mathrm{s}), \mathrm{K}$ is the shape parameter of Weibull distribution and 
it can be calculated based on Justus' theory using Equation (5) and $u_{R}$ is the rated wind speed $(\mathrm{m} / \mathrm{s})$. 2 MWwind turbine (G114-2.0) from Siemens Gamesa Renewable Energy company (Vizcaya, Spain) [56] was used in this study.

$$
\mathrm{K}=(\sigma / \overline{\mathrm{u}})^{-1.086}, 1 \leq \mathrm{K} \leq 10 .
$$

where $\overline{\mathrm{u}}$ is the mean wind speed at hub level $(\mathrm{m} / \mathrm{s})$, and $\sigma$ is the standard deviation of the wind speeds sample $(\mathrm{m} / \mathrm{s})$.

\subsection{Performance Assessment of the RES}

The harmony between the energy generation from the RESs and the demand can be inspected using the RES Fraction $\left(F_{R}\right)$ which represent the percentage of demand met by the RES. $F_{R}$ can be calculated as,

$$
F_{R}=\frac{D_{R}}{D}
$$

where $D_{R}$ is the hourly demand met by the RES (kWh) and $D$ is the hourly demand of Gwanda city $(\mathrm{kWh})$ where the daily demand of Gwanda was obtained from [38] while the hourly load profile for Gwanda city was approximated to be like the profile of a city in Zambia [57].

Moreover, in order to inspect the autonomy of the system the demand supply fraction (DSF) which is the number of hours in which the demand is totally met by the RES in a year over the total numbers of hours in a year and it can be calculated using Equation (7).

$$
D S F=\frac{H}{8760}
$$

where DSF is the demand supply fraction (\%); $H$ is the number of hours in which the demand is totally met by the RES in a year.

\subsection{The Economic Assessment of the Renewable Energy Systems (RES)}

The levelized cost of electricity (LCOE) is used to assess the economic feasibility of the RESs. LCOE of the energy systems can be found using Equation (8) where the effect of the mismatching between the demand and energy production is incorporated by using the demand met by the hybrid system instead of the energy generated.

$$
L C O E=\frac{C_{i}+\sum_{t=1}^{L} \frac{M_{t}}{(1+r)^{t}}}{\sum_{t=1}^{L} \frac{D_{R}}{(1+r)^{t}}}
$$

where $C_{i}$ is the capital cost of the RES (USD), $M_{t}$ is the annual maintenance cost of the RES (USD), $L$ is the lifetime of the system (years) where it is assumed that all the components will have the same lifetime and $\mathrm{r}$ is the annual discount rate. The economic parameters used in the analysis are shown in Table 1.

Table 1. The photovoltaic (PV) and wind systems economic parameters and the grid tariff in addition to the yearly discount rate for Gwanda city, Zimbabwe.

\begin{tabular}{ccc}
\hline Parameter & Value & Reference \\
\hline Photovoltaic system capital cost (USD/kW) & 1533 & {$[58,59]$} \\
Wind system capital cost (USD/kW) & 1516 & {$[58,59]$} \\
Photovoltaic maintenance cost (USD/kW) & 24.7 & {$[60]$} \\
Wind maintenance cost (USD/kW) & 39.53 & {$[61]$} \\
System expected lifetime (Years) & 25 & {$[59,62]$} \\
Grid tariff (USD/MWh) & 100 & {$[38]$} \\
Annual discount rate (\%) & 7.2 & {$[38]$} \\
\hline
\end{tabular}




\section{Results and Discussion}

Investment in renewable energy projects became attractive due to the profitability of such projects. Moreover, the deployment of RESs helps in the mitigation of greenhouse gases (GHGs) and at the same time ensures sufficient and secure energy sources. However, the significant drawback of RESs is the intermittency of the energy production from these systems due to the nature of the renewable energy resources which causes a mismatch between the demand and the supply and also affects the economics of the RESs.

The hybridization of RESs can overcome the intermittency of the resources and increase the harmony between the supply and the demand up to a certain limit where RESs can work in a synergistic way. Moreover, hybridization increases the economic benefits gained by the RESs which makes it more attractive to invest in. As the case study of this paper, Gwanda has a significant potential of wind and solar energy where the hybridization of these two resources proves that this option is the most suitable to achieve not only the maximum economic benefits but also the maximum technical benefits represented by the RES fraction, Figure 2 shows the increase in the technical feasibility of the renewable energy systems with the increase in the PV and wind capacities. However, it can be depicted from Figure 2 that after certain capacities' threshold is reached, the technical feasibility (represented by the RES fraction and the DSF) reaches saturation due to the mismatch between the demand and the supply which increase the electricity cost as shown in Figure 3. Hence, it vital to find the optimal PV and wind capacities that achieve the maximum technical and economic benefits, Table 2 shows the economic parameters as well as technical parameters of the maximum feasible capacities of PV, wind and PV-wind hybrid systems in Gwanda.

Table 2. The maximum feasible wind, PV and PV-wind hybrid systems capacities in Gwanda, Zimbabwe, in addition to their economic and technical parameters.

\begin{tabular}{cccc}
\hline Configuration & Wind & PV & PV-Wind \\
\hline PV Capacity (MW) & - & 1.41 & 1 \\
Wind Capacity (MW) & 2 & - & 2 \\
Capacity Factor (\%) & 34.57 & 18.72 & 29.29 \\
RES Fraction (\%) & 54.99 & 28.72 & 65.07 \\
DSF (\%) & 32.55 & 9.57 & 42.03 \\
LCOE (USD/kWh) & 0.09 & 0.10 & 0.10 \\
NPV (million USD) & 3.00 & 0.087 & 3.06 \\
IRR (\%) & 17 & 7.65 & 14.04 \\
PBP (years) & 5 & 13.1 & 3.94 \\
\hline
\end{tabular}

Note that in Table 2, the hybrid system does not have the highest RES fraction and DSF only, i.e., the highest technical feasibility but also it has the highest NPV and the lowest payback period (PBP) which means that the hybrid system in Gwanda achieves the maximum economic and technical benefits compared with separate systems where solar and wind resources complement each other in a synergistic way. Moreover, note that the PV system alone has the lowest RES fraction, DSF and the lowest economic benefits since it has the lowest capacity factor among the other options due to the nature of the solar resources where on average the PV meets totally the demand of Gwanda for two hours only in a day while the wind system on average meets the demand for five hours. On the other hand, the hybrid PV/wind system meets on average the demand nine hours a day. Figure 4 shows the average hourly demand of Gwanda as well as the average hourly energy generation from the maximum feasible PV, wind and PV-wind hybrid systems.

Note that in Figure 4, the hybridization between solar and wind systems achieves synergistic performance that increases the fraction of demand met by the RES and increases the autonomy of the RES system. Figure 5 shows the monthly RES fraction and demand supply fraction of the maximum feasible PV, wind and PV-wind systems in Gwanda. 


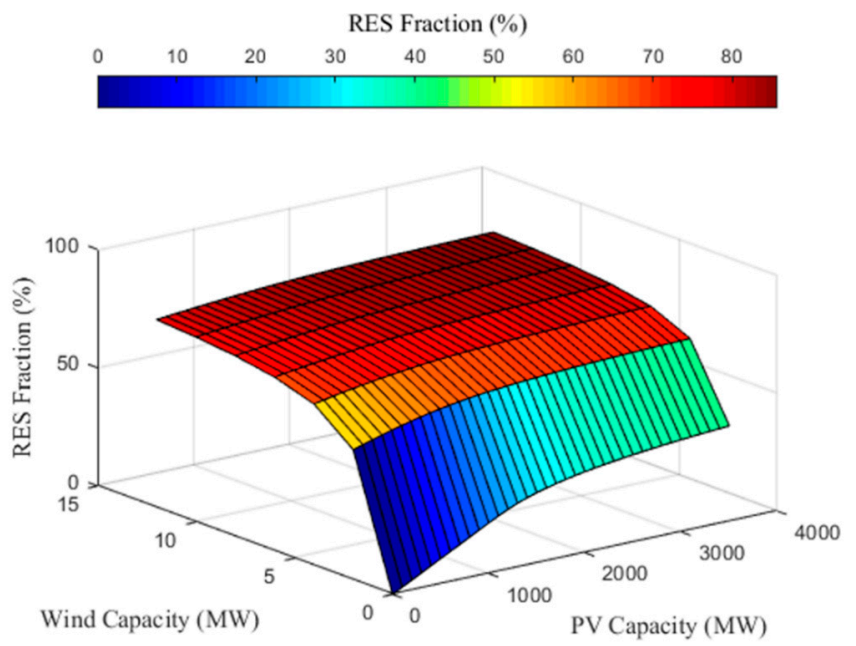

(a)

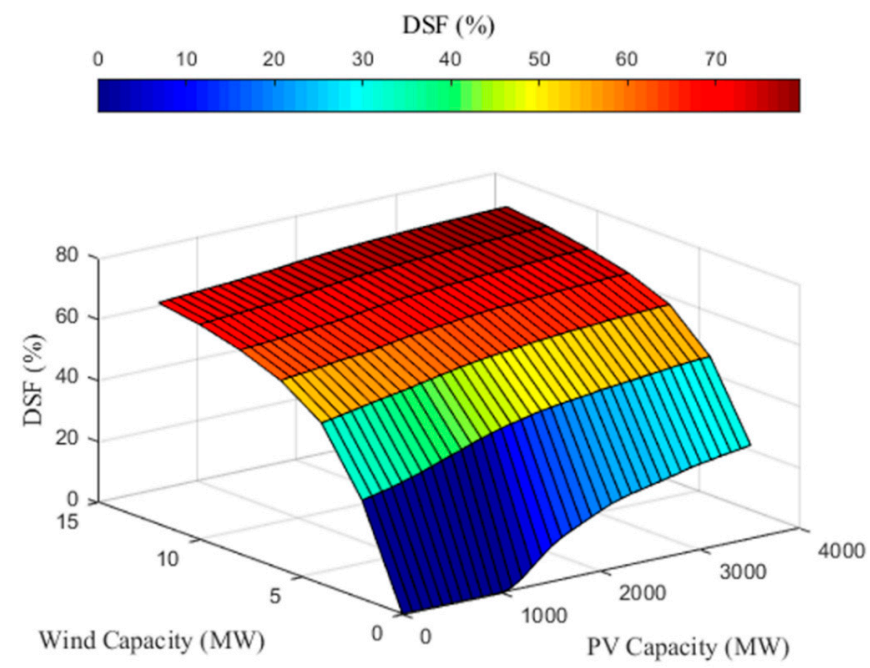

(b)

Figure 2. The technical parameters of different PV/wind hybrid system sizes in Gwanda: (a) renewable energy systems (RES) fraction and (b) demand supply fraction.

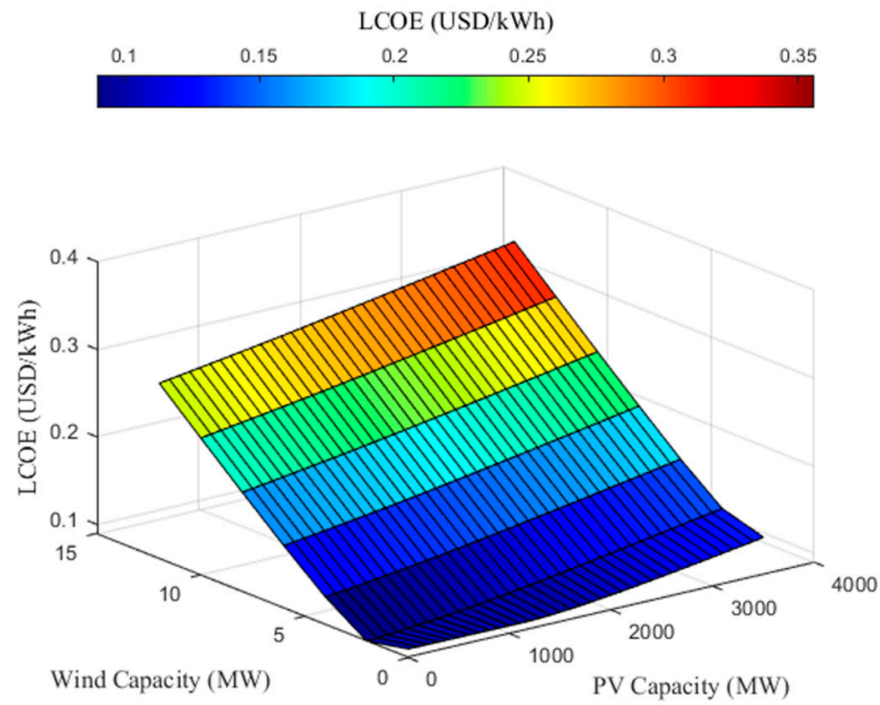

Figure 3. The levelized cost of electricity (LCOE) of different PV/wind hybrid system sizes in Gwanda. 


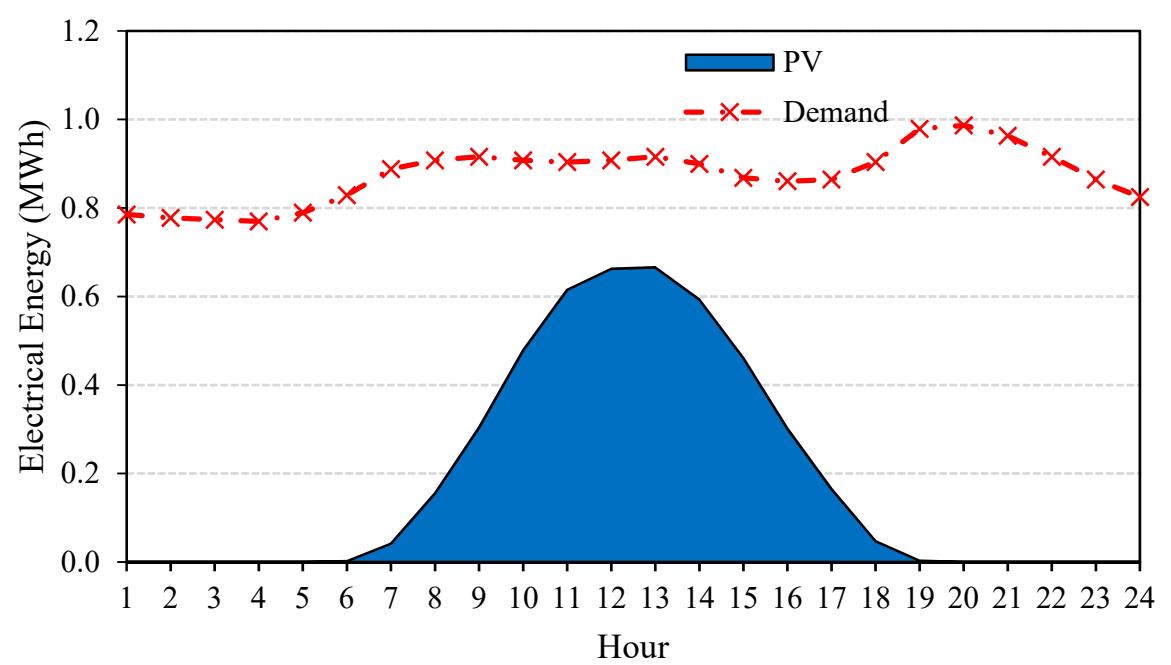

(a)

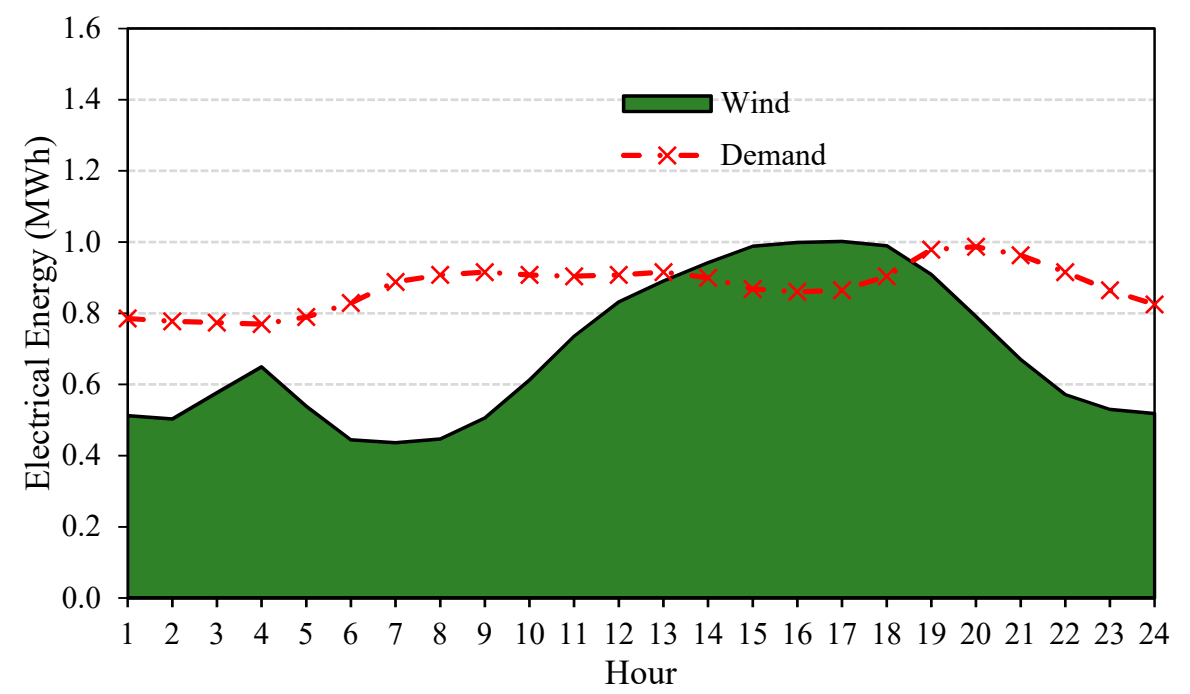

(b)

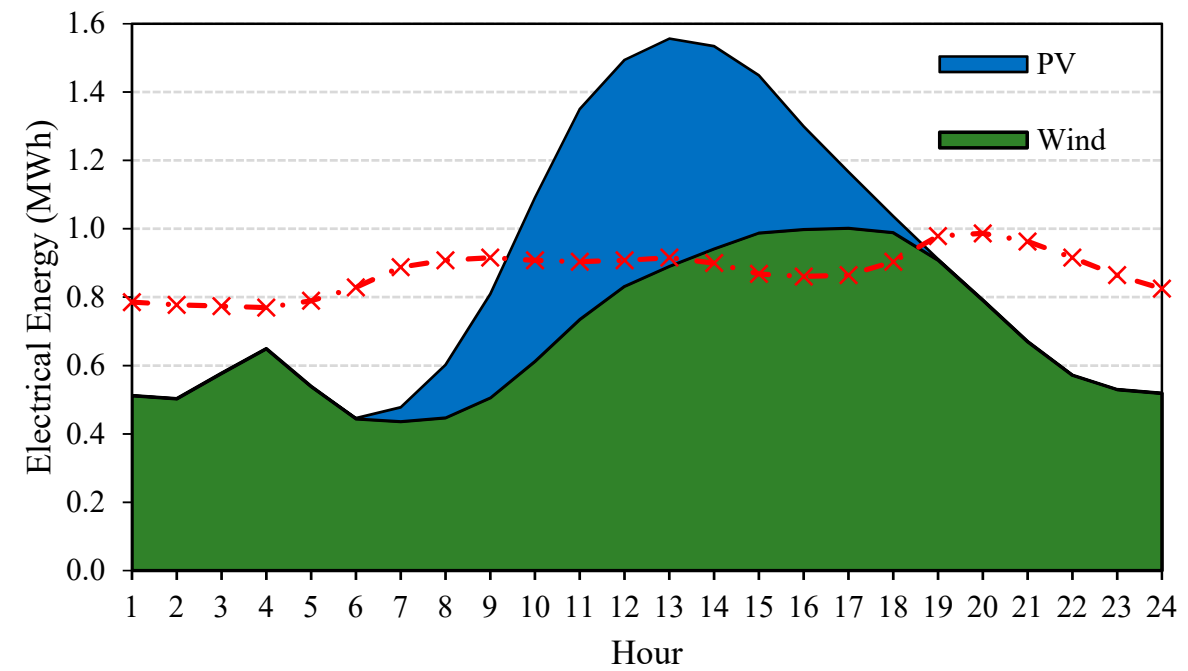

(c)

Figure 4. The average hourly energy generation from the maximum feasible: (a) PV system, (b) wind system and (c) PV-wind hybrid system in addition to the average hourly demand of Gwanda. 


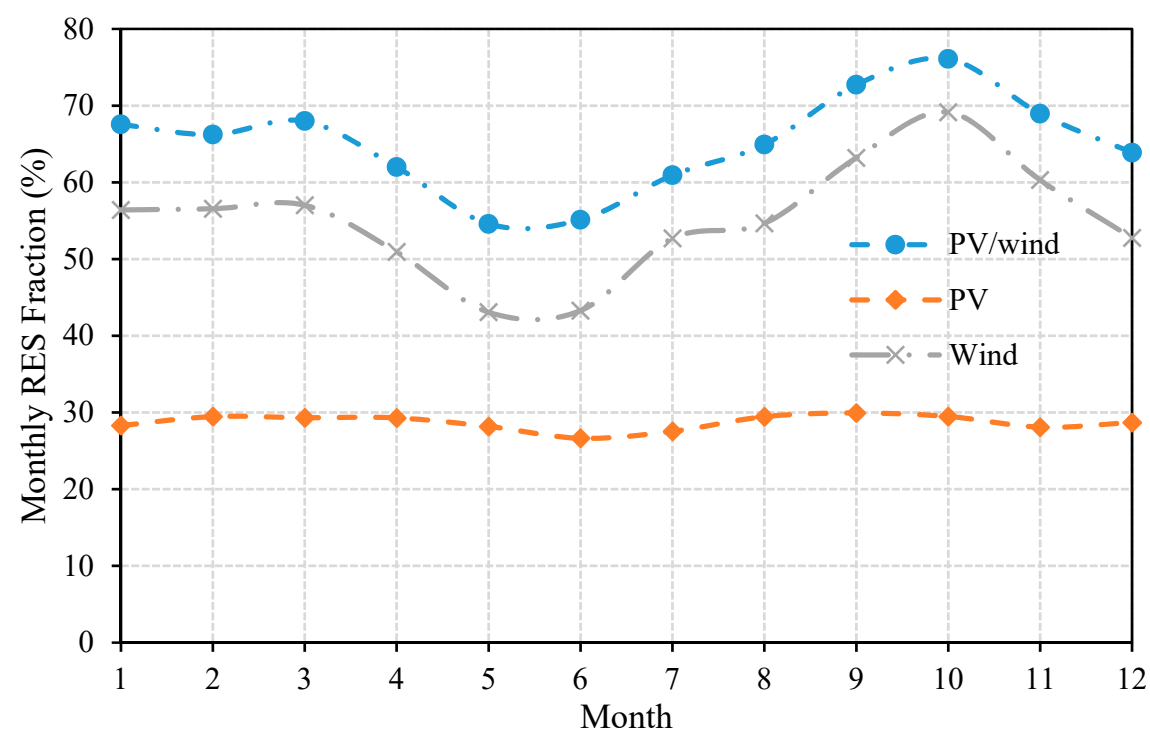

(a)

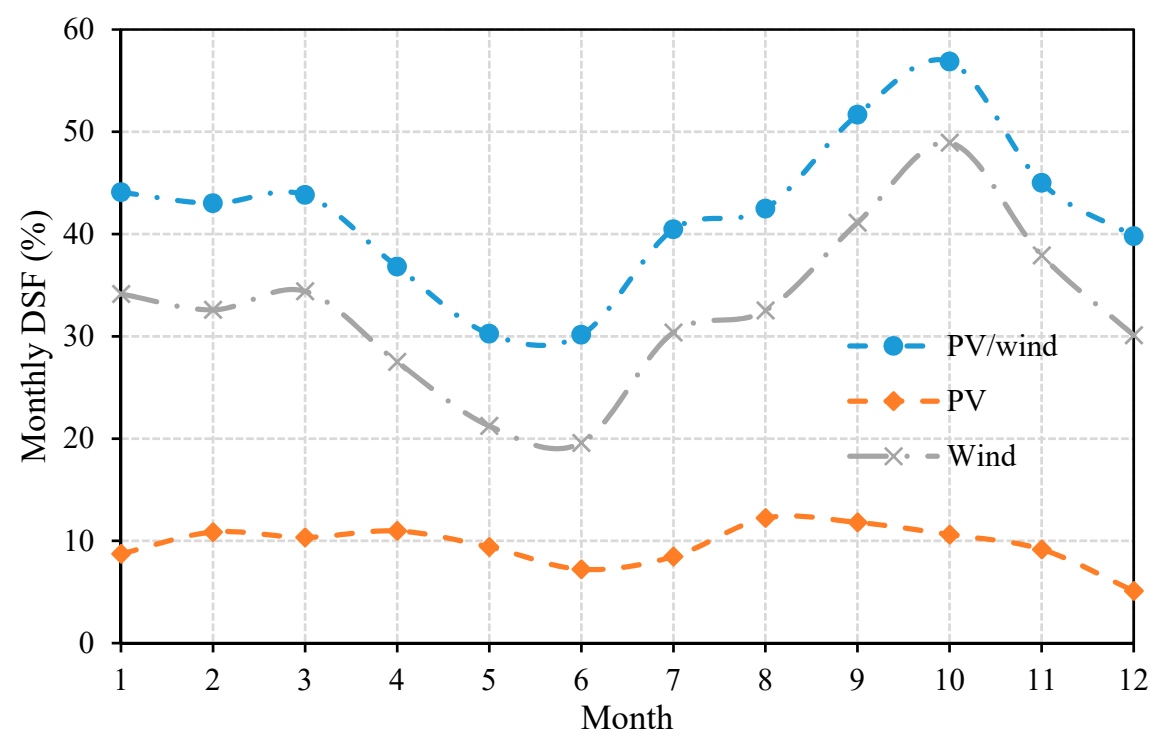

(b)

Figure 5. The monthly technical parameters of the maximum feasibly RESs: (a) RES fraction and (b) demand supply fraction.

Note that in Figure 5 the maximum RES fraction and DSF occur in October where this month has the highest wind resources and the highest solar resources throughout the year while the lowest RES fraction and DSF occur in May and June since these months have the lowest wind resources and the lowest solar resources. The proposed system in this study had better economic and technical feasibilities compared with similar renewable energy systems either standalone PV and wind systems or hybrid PV/wind systems with and without energy storage systems at similar geographic locations in Africa, as shown in Table 3. 
Table 3. Techno-economic comparison of different systems at similar geographic locations in Africa.

\begin{tabular}{|c|c|c|c|c|c|}
\hline Paper & Location & System Type & LCOE (USD/kWh) & NPV (USD) & RES Fraction (\%) \\
\hline [63] & South Africa & Standalone PV & 0.16 & - & - \\
\hline [44] & South Africa & $\mathrm{PV} / \mathrm{CSP}$ & 0.16 & - & - \\
\hline [43] & Sub-Saharan Africa & Standalone PV & 0.83 & - & - \\
\hline [64] & Nigeria & Standalone PV & 0.40 & $590 \times 10^{3}$ & - \\
\hline [13] & Zimbabwe & Standalone PV & 0.10 & $29.3 \times 10^{6}$ & - \\
\hline [38] & Zimbabwe & Hybrid Wind/PV & 0.21 & - & 42 \\
\hline [15] & Zimbabwe & Hybrid PV/Wind-Battery & 0.10 & $39.13 \times 10^{3}$ & 60.47 \\
\hline [65] & Zimbabwe & Wind System & 0.13 & $7.8 \times 10^{6}$ & - \\
\hline This study & Zimbabwe & Hybrid PV/Wind & 0.1 & $3.06 \times 10^{6}$ & 65.07 \\
\hline
\end{tabular}

\section{Conclusions}

The hybridization between solar and wind systems partially solve the mismatch between the demand and the energy generation caused by the intermittency and the fluctuation of the resources and so increases the economic benefits of the RESs which makes it an attractive option to invest in. Solar and wind resources can complement each other and work in a synergistic way. Therefore, in order to prove that PV-wind hybrid system has better economics and performance compared with separate PV and wind systems, Gwanda city in Zimbabwe was the case study of this paper. The results indicate that the maximum feasible PV system in Gwanda-1.41 MW-has a RES fraction of 28.72\% and NPV of $87 \times 10^{3}$ USD while the maximum feasible wind system-2 MW-has a RES fraction of $55 \%$ and NPV of $3 \times 10^{6}$ USD. On the other hand, the maximum feasible PV/wind system-2 MW wind and $1 \mathrm{MW}$ PV-has RES fraction of $65.07 \%$ and NPV of $3.06 \times 10^{6}$ USD where it can be concluded that the PV-wind system did not only have the best technical performance but also the best economic benefit represented by the NPV and the PBP.

Author Contributions: Conceptualization, L.A.-G., R.S. and O.T.; methodology, L.A.-G. and O.T.; software L.A.-G.; validation, L.A.-G.; formal analysis, L.A.-G.; investigation, L.A.-G. and R.S.; resources, O.T. and M.F.; data curation, L.A.-G.; writing—original draft preparation, L.A.-G. and R.S.; writing—review and editing, L.A.-G., R.S., O.T. and M.F.; visualization, L.A.-G.; supervision, O.T. and M.F.; project administration, L.A.-G., O.T. and M.F. All authors have read and agreed to the published version of the manuscript.

Funding: This research received no external funding.

Acknowledgments: The authors would like to thank Derek Baker for providing the TMY data for Gwanda.

Conflicts of Interest: The authors declare no conflict of interest.

\section{References}

1. Al-Ghussain, L. Global warming: Review on driving forces and mitigation. Environ. Prog. Sustain. Energy 2018, 38, 13-21. [CrossRef]

2. Al-Ghussain, L.; Al-Oran, O.; Lezsovits, F. Statistical Estimation of Hourly Diffuse Radiation Intensity of Budapest City. Environ. Prog. Sustain. Energy 2020. [CrossRef]

3. Hosseini, S.E. An outlook on the global development of renewable and sustainable energy at the time of COVID-19. Energy Res. Soc. Sci. 2020, 68, 101633. [CrossRef]

4. Wilson, J.E.; Grib, S.W.; Ahmad, A.D.; Renfro, M.W.; Adams, S.A.; Salaimeh, A.A. Study of Near-Cup Droplet Breakup of an Automotive Electrostatic Rotary Bell (ESRB) Atomizer Using High-Speed Shadowgraph Imaging. Coatings 2018, 8, 174. [CrossRef]

5. Ahmad, A.D.; Abubaker, A.M.; Salaimeh, A.A.; Akafuah, N.K. Schlieren Visualization of Shaping Air during Operation of an Electrostatic Rotary Bell Sprayer: Impact of Shaping Air on Droplet Atomization and Transport. Coatings 2018, 8, 279. [CrossRef]

6. Darwish Ahmad, A.; Singh, B.B.; Doerre, M.; Abubaker, A.M.; Arabghahestani, M.; Salaimeh, A.A.; Akafuah, N.K. Spatial Positioning and Operating Parameters of a Rotary Bell Sprayer: 3D Mapping of Droplet Size Distributions. Fluids 2019, 4, 165. [CrossRef]

7. Najjar, Y.S.H.; Abubaker, A.M. Exergy analysis of a novel inlet air cooling system with gas turbine engines using cascaded waste-heat recovery. Int. J. Exergy 2017, 22, 183-204. [CrossRef] 
8. Abubaker, A.M.; Najjar, Y.S.H.; Ahmad, A.D. A Uniquely Finned Tube Heat Exchanger Design of a Condenser for Heavy-Duty Air Conditioning Systems. Int. J. Air Cond. Refrig. 2020, 28, 2050004. [CrossRef]

9. Najjar, Y.S.H.; Abubaker, A.M.; El-Khalil, A.F.S. Novel inlet air cooling with gas turbine engines using cascaded waste-heat recovery for green sustainable energy. Energy 2015, 93, 770-785. [CrossRef]

10. Najjar, Y.S.H.; Abubaker, A.M. Using novel compressed-air energy storage systems as a green strategy in sustainable power generation-A review. Int. J. Energy Res. 2016, 40, 1595-1610. [CrossRef]

11. Najjar, Y.S.H.; Abubaker, A.M. Indirect evaporative combined inlet air cooling with gas turbines for green power technology. Int. J. Refrig. 2015, 59, 235-250. [CrossRef]

12. Ahmad, A.D.; Abubaker, A.M.; Najjar, Y.S.H.; Manaserh, Y.M.A. Power boosting of a combined cycle power plant in Jordan: An integration of hybrid inlet cooling \& solar systems. Energy Convers. Manag. 2020, $214,112894$.

13. Samu, R.; Fahrioglu, M. An analysis on the potential of solar photovoltaic power. Energy Sources Part B Econ. Plan. Policy 2017, 12, 883-889. [CrossRef]

14. Jingura, R.M.; Matengaifa, R. Rural energy resources and agriculture's potential as an Energy producer in Zimbabwe. Energy Sources Part B Econ. Plan. Policy 2009, 4, 68-76. [CrossRef]

15. Al-Ghussain, L.; Samu, R.; Fahrioglu, M. Techno-Economic Feasibility of PV/Wind-Battery Storage: Case Analysis in Zimbabwe. In Proceedings of the 16th International Conference on Clean Energy (ICCE-2018), Famagusta, Cyprus, 9-11 May 2018; pp. 9-11.

16. Al-Ghussain, L.; Samu, R.; Taylan, O.; Fahrioglu, M. Techno-Economic Analysis of Photovoltaic-Hydrogen Fuel Cell/Pumped Hydro Storage System for Micro Grid Applications: Case Study in Cyprus. In Proceedings of the 2018 International Conference on Photovoltaic Science and Technologies (PVCon), Ankara, Turkey, 4-6 July 2018; pp. 1-6.

17. Al-Ghussain, L.; Ahmed, H.; Haneef, F. Optimization of hybrid PV-wind system: Case study Al-Tafilah cement factory, Jordan. Sustain. Energy Technol. Assess. 2018, 30, 24-36. [CrossRef]

18. Al-Ghussain, L.; Taylan, O. Sizing methodology of a PV/wind hybrid system: Case study in cyprus. Environ. Prog. Sustain. Energy 2019, 38, e13052. [CrossRef]

19. Al-Ghussain, L.; Taylan, O.; Baker, D.K. An investigation of optimum PV and wind energy system capacities for alternate short and long-term energy storage sizing methodologies. Int. J. Energy Res. 2018, 1-15. [CrossRef]

20. Al-Ghussain, L.; Samu, R.; Taylan, O.; Fahrioglu, M. Sizing Renewable Energy Systems with Energy Storage Systems in Microgrids for Maximum Cost-Efficient Utilization of Renewable Energy Resources. Sustain. Cities Soc. 2020, 55, 102059. [CrossRef]

21. Abujubbeh, M.; Marazanye, V.T.; Qadir, Z.; Fahrioglu, M.; Batunlu, C. Techno-Economic Feasibility Analysis of Grid-Tied PV-Wind Hybrid System to Meet a Typical Household Demand: Case Study-Amman, Jordan. In Proceedings of the 2019 1st Global Power, Energy and Communication Conference (GPECOM), Nevsehir, Turkey, 12-15 June 2019; pp. 418-423.

22. Rashid, M.; Abujubbeh, M.; Fahrioglu, M. Improving capacity factor of transmission lines by hybridizing CSP with wind. In Proceedings of the 2017 4th International Conference on Electrical and Electronic Engineering (ICEEE), Ankara, Turkey, 8-10 April 2017.

23. Abujubbeh, M.; Fahrioglu, M. Determining Maximum Allowable PV Penetration Level in Transmission Networks: Case Analysis-Northern Cyprus Power System. In Proceedings of the 2019 1st Global Power, Energy and Communication Conference (GPECOM), Nevsehir, Turkey, 12-15 June 2019; pp. 292-297.

24. Reiniger, K.; Schottland, T.; Zeidler, A. Optimization of Hybrid Stand-alone systems. In Proceedings of the European Wind Energy Association Conference and Exhibition, Rome, Italy, 7-9 October 1986.

25. Contaxis, G.C.; Kabouris, J. Short-term scheduling in a wind dieselautonomous energy system. IEEE Trans. Power Syst. 1991, 6, 1161-1167. [CrossRef]

26. Singh, G.; Baredar, P.; Singh, A.; Kurup, D. Optimal sizing and location of PV, wind and battery storage for electrification to an island: A case study of Kavaratti, Lakshadweep. J. Energy Storage 2017, 12, 78-86. [CrossRef]

27. Sadati, S.M.S.; Jahani, E.; Taylan, O.; Baker, D.K. Sizing of Photovoltaic-Wind-Battery Hybrid System for a Mediterranean Island Community Based on Estimated and Measured Meteorological Data. J. Sol. Energy Eng. 2018, 140, 011006. [CrossRef] 
28. Azerefegn, T.M.; Bhandari, R.; Ramayya, A.V. Techno-economic analysis of grid-integrated PV/wind systems for electricity reliability enhancement in Ethiopian industrial park. Sustain. Cities Soc. 2020, 53, 101915. [CrossRef]

29. Bortolini, M.; Gamberi, M.; Graziani, A. Technical and economic design of photovoltaic and battery energy storage system. Energy Convers. Manag. 2014, 86, 81-92. [CrossRef]

30. Al-assad, R.; Ayadi, O. Techno-Economic Assessment of Grid Connected Photovoltaic Systems in Jordan. In Proceedings of the 2017 8th International Renewable Energy Congress (IREC), Amman, Jordan, 21-23 March 2017; pp. 1-4.

31. Pradhan, S.R.; Sahoo, S.P.; Das, R.; Priyanka, S. Design of Off-Grid Home with Solar-Wind-Biomass Energy. Int. J. Eng. Res. Appl. 2014, 4, 76-81.

32. Mehrpooya, M.; Mohammadi, M.; Ahmadi, E. Techno-economic-environmental study of hybrid power supply system: A case study in Iran. Sustain. Energy Technol. Assess. 2018, 25, 1-10. [CrossRef]

33. Jurasz, J.; Campana, P.E. The potential of photovoltaic systems to reduce energy costs for office buildings in time-dependent and peak-load-dependent tariffs. Sustain. Cities Soc. 2019, 44, 871-879. [CrossRef]

34. El-Tous, Y.; Al-Battat, S.; Abdel, H.S. Hybrid Wind-PV grid connected Power Station Case Study: Al-Tafila, Jordan. Int. J. Energy Environ. 2012, 3, 605-616.

35. Al-Masri, H.; Amoura, F. Feasibility Study of A Hybrid Wind/PV System Connected to the Jordanian Grid. Int. J. Appl. Power Eng. 2013, 2. [CrossRef]

36. Benlouba, S.; Bourouis, M. Feasibility Study of a Wind-Photovoltaic Power generation System for a remote area in the extreme south of Algeria. Appl. Energy 2016, 99, 713-719. [CrossRef]

37. Ashok, S. Optimised model for community-based hybrid energy system. Renew. Energy 2007, 32, 1155-1164. [CrossRef]

38. Samu, R.; Fahrioglu, M.; Taylan, O. Feasibility Study of a Grid Connected Hybrid PV-Wind Power Plant in Gwanda, Zimbabwe. In Proceedings of the IEEE Honet Symposium, Nicosia, Cyprus, 13 October 2016; pp. 122-126.

39. Asumadu-Sarkodie, P.A.; Owusu, S. The potential and economic viability of solar photovoltaic power in Ghana. Energy Sources Part A 2016, 38, 709-716. [CrossRef]

40. Adaramola, M. Viability of grid-connected solar PV energy system in Jos, Nigeria. Int. J. Electr. Power Energy Syst. 2014, 61, 64-69. [CrossRef]

41. Kebede, K.Y. Viability study of grid-connected solar PV system in Ethiopia. Sustain. Energy Technol. Assess. 2015, 10, 63-70. [CrossRef]

42. L-Shimy, M.E. Viability analysis of PV power plants in Egypt. Renew. Energy 2009, 34, 2187-2196. [CrossRef]

43. Baurzhan, S.; Jenkins, G. Off-grid solar PV: Is it an affordable or appropriate solution for rural electrification in Sub-Saharan African countries? Renew. Sustain. Energy Rev. 2016, 60, 1405-1418. [CrossRef]

44. Pan, C.A.; Dinter, F. Combination of PV and central receiver CSP plants for base load power generation in South Africa. Sol. Energy 2017, 146, 379-388. [CrossRef]

45. Chahuruva, R.; Dei, T. Study on Isolated Solar Home Systems for Application in Zimbabwe. Energy Procedia 2017, 138, 931-936. [CrossRef]

46. Ziuku, S.; Seyitini, L.; Mapurisa, B.; Chikodzi, D.; van Kuijk, K. Potential of Concentrated Solar Power (CSP) in Zimbabwe. Energy Sustain. Dev. 2014, 23, 220-227. [CrossRef]

47. Mentis, D.; Hermann, S.; Howells, M.; Welsch, M.; Siyal, S. Assessing the technical wind energy potential in Africa a GIS-based approach. Renew. Energy 2015, 83, 110-125. [CrossRef]

48. Fant, C.; Gunturu, B.; Schlosser, A. Characterizing wind power resource reliability in southern Africa. Appl. Energy 2016, 161, 565-573. [CrossRef]

49. Bogno, B.; Sali, M.; Aillerie, M. Technical and Economic Analysis of a Wind Power Generation System for Rural Electrification in Subequatorial Area of Africa. Energy Procedia 2014, 50, 773-781. [CrossRef]

50. Kazet, M.; Mouangue, R.; Kuitche, A.; Ndjaka, J.M. Wind Energy Resource Assessment in Ngaoundere Locality. Energy Procedia 2016, 93, 74-81. [CrossRef]

51. Ministry of Energy and Power Development. National Renewable Energy Policy; Ministry of Energy and Power Development: Harare, Zimbabwe, 2019.

52. Dubey, S.; Sarvaiya, J.; Seshadri, B. Temperature dependent photovoltaic (PV) efficiency and its effect on PV production in the world-A review. Energy Procedia 2013, 33, 311-321. [CrossRef]

53. Canadian Solar. Photovoltaic Panels Datasheet; Canadian Solar: Guelph, ON, Canada, 2017. 
54. Duffie, J.; Beckman, W. Solar Engineering of Thermal Processes, 3rd ed.; Wiley: Hoboken, NJ, USA, 2006.

55. Manwell, J.F.; McGowan, J.G.; Rogers, A.L. Wind Energy Explained: Theory, Design and Application, 2nd ed.; Wiley: Chichester, UK, 2009.

56. Gamesa. Greater Energy Produced From Low and Medium Wind Sites; Gamesa: Zamudio, Spain, 2014.

57. Tembo, B.; Merven, B. Policy options for the sustainable development of Zambia's electricity sector. J. Energy S. Afr. 2013, 24, 16-27. [CrossRef]

58. Fichter, T.; Trieb, F.; Moser, M.; Kern, J. Optimized integration of renewable energies into existing power plant portfolios. Energy Procedia 2013, 49, 1858-1868. [CrossRef]

59. Al-Ghussain, L.; Taylan, O.; Fahrioglu, M. Sizing of a Photovoltaic-Wind Oil Shale Hybrid System: Case Analysis in Jordan. J. Sol. Energy Eng. Incl. Wind Energy Build. Energy Conserv. 2018, 140, 1-12. [CrossRef]

60. Sangster, A.J. Solar Photovoltaics. Green Energy Technol. 2014, 194, 145-172.

61. Breeze, P. Wind Power. Power Gener. Technol. 2014, 1, 223-242.

62. Yang, H.; Wei, Z.; Chengzhi, L. Optimal design and techno-economic analysis of a hybrid solar-wind power generation system. Appl. Energy 2009, 86, 163-169. [CrossRef]

63. Numbi, B.P.; Malinga, S.J. Optimal energy cost and economic analysis of a residential grid-interactive solar PV system-case of eThekwini municipality in South Africa. Appl. Energy 2017, 186, 28-45. [CrossRef]

64. Okoye, C.O.; Oranekwu-Okoye, B.C. Economic feasibility of solar PV system for rural electrification in Sub-Sahara Africa. Renew. Sustain. Energy Rev. 2018, 82, 2537-2547. [CrossRef]

65. Samu, R.; Fahrioglu, M.; Ozansoy, C. The potential and economic viability of wind farms in Zimbabwe. Int. J. Green Energy 2019, 1-8. [CrossRef]

(C) 2020 by the authors. Licensee MDPI, Basel, Switzerland. This article is an open access article distributed under the terms and conditions of the Creative Commons Attribution (CC BY) license (http://creativecommons.org/licenses/by/4.0/). 